\title{
Conclusions: Criminal Policy on Illicit Tobacco Trade Between Scylla of Health Concerns and Charybdis of Fiscal Interests
}

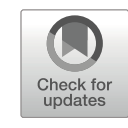

\author{
Konrad Buczkowski and Celina Nowak
}

\begin{abstract}
This chapter summarizes the research findings presented in the chapters on national criminal policies above in this volume. It also puts forward some recommendations to national policy makers aimed at improving national criminal policies on illicit tobacco trade.
\end{abstract}

This volume presents a comprehensive analysis of criminal policies that govern the illicit tobacco trade and that have been adopted by six of the Member States of the European Union. This comparative chapter identifies common features of these policies and summarizes the research to prepare for deeper examination and to support practical application by national policymakers.

The research on national systems confirms the preliminary presumption underlying the research that on the national level, the fight against the illicit trade of tobacco products is primarily conducted through the enforcement of criminal law. It issues from the chapters above that administrative (tax or fiscal) law play a secondary, subsidiary role with regard to the criminal legal framework.

The main goals of any national criminal law are to prevent crime (primarily by deterrence), bring offenders to justice and enforce sanctions. Effectiveness of criminal law is very difficult to assess, as evaluation criteria (such as for instance a decrease of the number of committed offences or the increase of the number of convictions) are fluent and, even if agreed upon by researchers, they change over time. However, attempting to pinpoint "an effective way to fight against illicit

\footnotetext{
K. Buczkowski $(\bowtie)$

Institute of Law Studies, Polish Academy of Sciences, Department of Criminal Law, Warsaw,

Poland

e-mail: k.buczkowski@inp.pan.pl

C. Nowak

Institute of Law Studies, Polish Academy of Sciences, Warsaw, Poland

e-mail: cnowak@inp.pan.pl 
tobacco trade", we should first emphasise the following goals in tackling this type of crime: to reduce the consumption of tobacco (as required by the WHO FCTC), decrease the volume of tobacco products illegally distributed in states and secure steady fiscal revenue for the state's budget.

The countries must translate these goals into legislation while taking a variety of factors into account. First, there are serious health considerations related to tobacco use. However states decide to shape their criminal law, the issue of health remains of utmost importance and constitutes a primary concern.

Additionally, states must fulfil their international obligations as well as their obligations to the EU legal instruments. These instruments, as mentioned previously, articulate a variety of measures to reduce the demand and supply of tobacco. Those measures may be repressive, regulatory or preventive. Repressive measures establish a catalogue of unlawful behaviours in national policy and enforce them with effective, proportionate and dissuasive criminal or non-criminal sanctions, including monetary sanctions. Regulatory measures establish fiscal policies that comply with respective EU instruments, as well as establish a track and trace system. Preventive instruments mainly govern advertising, packaging and the labelling of tobacco products.

Furthermore, as mentioned above, national criminal policy on the illicit tobacco trade is just an element of the general national criminal policy. Therefore, it must conform to a state's response to other types of criminality. Thus, the criminal policy regarding illicit tobacco trade must be compatible with the general legal rules of the national law, most significantly rules referring to criminal law and criminal procedure.

Finally, criminal law never occurs in a void. It is created by states situated in different geographical locations with, therefore, different histories and legal backgrounds. These geographical, economic, political and social circumstances impact states' experiences with the illicit tobacco trade and on how they cope with this phenomenon.

The studies presented in this collection are proof of the fact that, to different extents and in different ways, the six states examined here struggle to find an effective response to the illicit tobacco trade.

The states presented in this volume have very diverse circumstances. Four states: Lithuania, Poland, Slovakia and Romania, which are the newer EU Member States, are all located on the Eastern EU border. Lithuania has a small population but shares a long land border with much poorer countries, such as Belarus and Russia. Poland is the largest of the four states, in terms of both population and territory. It has a long land border with non-EU countries, most notably with Belarus and Ukraine. Both Lithuanian and Polish eastern borders are easily accessible - they cross flat plains and woods and occasional rivers are their only natural obstacles. Slovakia's eastern neighbour is Ukraine, and their shared border is more difficult terrain, especially in the mountains. The borders of Romania on the east are long. Parts thereof are somewhat difficult to cross because of the mountains, but the Romanian border with Moldova is fluvial, following the river Prut. Also, all these counties struggle with their post-communist heritage, one of the element of which are rather difficult economic situations of their populations. Large groups of inhabitants have emigrated over the years to richer states in the west and north of the continent. 
Germany has the strongest economy of the examined states. Also, it has a more convenient geographical location than any of the examined states. It is situated in the middle of the continent. Italy, on the other hand, may be richer than the four Eastern states, but is in the south of the continent and has a long waterfront border.

The economic situation of citizens also greatly influences the size of the illicit tobacco trade. The poorer populations east of the EU, who often have strong personal ties with people living across the EU eastern border, are more likely to buy cheaper illegal cigarettes or to contribute to illegal trade than populations from western EU countries. They may, for instance, be more inclined to take bribes from individuals involved in this illegal activity. Also, general social attitudes toward crime, including corruption, are important.

The research shows that the practices used to illicitly trade tobacco products are similar in all examined states. The criminals still use individual, small-scale smugglers, as they had been over the years, or organize and engage in large criminal operations. In addition, in recent years smugglers have been using modern technologies, such as drones, to pursue their illegal activities. With the improvement of detection techniques on the Eastern border of the Union, more organized crime groups have given up smuggling and started opening factories inside these states to avoid having to pass through borders. They manufacture illicit cigarettes and then sell them inside a given country or push them further to the West, to gain more profit as prices of legal cigarettes are higher on the West.

All national policymakers in the examined states rely upon criminal law instruments to combat the illicit tobacco trade. Therefore, in all these states this activity is recognised as a crime. As stated in Art. 15 WHO FCTC, the phrase 'illicit tobacco trade' covers a variety of activities, such as smuggling, tax evasion, manufacturing and counterfeiting. The research shows that-from the point of view of criminalisation-in all the examined countries all of the features of illicit tobacco trade enumerated in Art. 15 WHO FCTC are covered. However, in some countries (Germany, Italy, Lithuania) due to the particularities of their respective national legal systems and the hierarchy of legal goods covered by criminal law, when the value or volume of illicitly traded tobacco products remains under a specified threshold, the activity is usually covered by administrative law. The latter solution implies financial sanctions, but not custodial sanctions, which are applied only with regard to perpetrators of crimes. Criminal law thus refers to more serious cases, more detrimental to the fiscal interests of the state. In other countries the criminal liability and administrative liability are independent and may be applied in parallel. In Poland and Romania, aside from administrative liability, depending upon the value of the damage to the public finances, perpetrators may be held liable for offences or for contraventions, the latter constituting a lesser form of criminal liability. Despite these rather complicated typologies of prohibited acts under respective national laws, interestingly, in general the ne bis in idem principle does not constitute an obstacle for states in prosecuting illicit tobacco trade, as the legal systems provides for some, even if imperfect, collision rules.

The overall positive assessment of the level of criminalisation of the illicit tobacco trade in the examined legal systems is diminished by the realization that 
in some examined countries sanctions on the illicit tobacco trade, which always depend upon the role and specific activity of the perpetrator, are less severe than for violent crimes (Poland, Germany). In other countries though the sanctions are quite severe in comparison to the other examined legal systems (Lithuania, Romania), amounting up to several years of imprisonment, although these systems present a general higher level of punitiveness, which is symptomatic for post-communist countries.

Overall, the illicit tobacco trade is often perceived as less serious criminal activity - and an occasional severity of applied sanctions is a result of general punitiveness of national criminal policy. The general perception, although stereotypical, is that this is a victimless violation of complicated financial rules that are incomprehensible for the average citizen. The crime is considered even less harmful than other types of economic crimes. Especially in Eastern Europe, where remnants of Soviet mentality and distrust towards authorities are still present, perpetrators of this type of criminality are met with limited social reprehension. They are lauded for outsmarting and gaining profit from a fiscal system that is unfavourable to ordinary people.

The effectiveness of the system of sanctions gives room for improvement in all the examined countries. In particular the application of financial penalties and forfeiture should be more effective. Sadly, enforcement of fines as well as asset recovery seem to be a challenge throughout. Criminals are not prevented from hiding their assets, and the sanction becomes void, when there is nothing to forfeit.

It is interesting to note that in all the examined states the national law provides for the responsibility of individuals, as well as legal persons for the said offences, with the notable exception of Germany. Germany does not allow for criminal liability of legal persons and only recognises some administrative liability of corporations. Yet, when provided, liability of legal persons for offences is only symbolic, hardly ever applied in practice.

The illicit tobacco trade in all its forms is usually an activity undertaken by a group of individuals. As mentioned above, a tendency is observed that organized crime groups have gotten more involved in the illicit tobacco trade in recent years. Sanctions for the illicit trade of tobacco products are less severe than, for instance, for drug offences. The risks are generally lower, due to the ambiguous social image of illicit tobacco manufacturers and smugglers. It is therefore important to note than in some of the examined legal systems (Germany, Italy, Romania) the fact that the illicit trade involved more than one person, or it involved organized crime, may warrant an increase in sanctions. It is therefore recommended to all other states to consider commission of illicit tobacco trade by more than one person, especially as part of activities of organized crime groups, an aggravating circumstance in the process of sentencing.

To sum up, we recommend a thorough assessment of the system of criminal and administrative sanctions and penalties that deter engagement in the illicit tobacco trade. We does not advocate for a general introduction of severe sanctions but recommend for the states to consider introducing a penalty of imprisonment or higher financial sanctions for more serious cases of illicit tobacco trade. The 
enforcement of financial penalties and forfeiture, as well as asset recovery should be more effective.

Also, the inevitability of sanctions seems crucial, so it must be recommended to conduct criminal proceedings in an expedite manner, especially with regard to less serious cases of illicit tobacco trade. In addition, national systems of liability of legal persons should be revised and made efficient in order to deter legal persons from encouraging or participating in illicit tobacco trade.

The national criminal policies that govern the illicit tobacco trade have some of the weaknesses as criminal policies adopted with regard to other types of crime. The level of criminalisation and sanctions are satisfactory, but the enforcement of the provisions needs improvement.

National enforcement is the domain of specialised law enforcement institutions, such as the financial police. Different agencies usually share the task of fighting the illicit tobacco trade on a national level. They cooperate, but at times this cooperation could be better. All enforcement agencies experience the same problems. Lack of resources has been pointed out as an issue; not enough funds, not enough trained staff, who are not paid well enough to abstain from taking an occasional bribe. It should be mentioned that the modus operandi of organised crime groups evolves. Law enforcement institutions face creative perpetrators operating more and more advanced technologies and thus, evading detection. Therefore, the material situation of investigative agencies should definitely be improved.

Still, more importantly, effective cooperation is not just about money. Lack of communication and exchange of experiences with partners inside and outside the country seem more troublesome than the lack of appropriate resources. The different law enforcement stakeholders should be cooperating and swiftly communicating with one another, instead of disputing over competencies or jurisdiction. We must consider the difficulties of conducting investigative operations of the organised crime groups involved in the illicit tobacco trade. These investigations are rarely supported by local communities. Coordination of law enforcement activities aimed at preventing and combating illicit tobacco trade should be a priority for national policymakers and the law enforcement authorities themselves, this is undoubtedly one of the most important recommendations resulting from the study at hand.

Another recommendation, based on the research presented in this collection, refers to the availability of data on the illicit tobacco trade. As observed by the research team and mentioned in the chapters above, no detailed and comprehensive data on criminality related to illicit tobacco trade are systematically collected in any of the examined states. If they exist, such data are part of data collected about general categories of related crimes, such as smuggling, tax evasion or lack of excise tax labels. Therefore, it is impossible to single out the data on tobacco-related crime. For this reason, such data are unavailable (Italy, Slovakia, Romania). Furthermore, pertinent data are often collected by more than one institution. Sometimes they are included in statistical data gathered in databases run by different institutions (fiscal administration, border guards), which assesses the real scope of the phenomenon (Poland, Germany). For the abovementioned reasons, evaluation of the so-called "dark number" of tobacco-related crimes is extremely problematic. The lack of 
detailed data will flaw all estimates, and the margin of error will be large. For the sake of future research on this topic, national law enforcement authorities should collect detailed and systematic data on the illicit tobacco trade and tobacco-related crimes. Without such data, conducting criminological studies in this field will be difficult.

All the examined states have implemented at least some preventive measures aimed at reducing tobacco demand, such as bans on advertising tobacco products or rules related to the packaging and labelling of tobacco products. Some countries adopt new methods to combat illicit trade, for instance in Italy authorities may prohibit access to web pages through which foreign tobacco products are illegally sold or advertised, which is a good solution limiting access to illegal products and must be recommended to be more widely adopted.

Also, EU Member States, as of 20 May 2019, have all adopted the EU track and tracing system of cigarettes, stipulated in Art. 15 and 16 of the Tobacco Products Directive 2014/40/EU.

Yet, states cannot easily find remedies to the uneven cigarette prices, which is the main contributor to the illicit tobacco trade, across EU Member States, as well as UE Member States and non-EU Member States. Smokers, notably in the eastern regions of Lithuania, Poland, Slovakia and Romania, as well as poorer smokers in other parts of these countries and smokers in Western states, tend to smoke illicit cigarettes, be it in the form of so-called illicit whites (local Eastern brands, usually produced with raw materials of lesser quality) or counterfeited western brands of cigarettes, because they are considerably cheaper than legal cigarettes.

There may be ways to change this landscape of varying prices, but none of them is satisfactory and each would certainly have unwanted ramifications. Prices in the different EU Member States could all be equalized, lowered to the current lowest legal level or increased to the current highest level. Neither of these scenarios is good though. Prices that are too high would push smokers to the dark market, which would be bad for their health, as well as bad for national public revenues. On the other hand, prices that are too low would make cigarettes so affordable they would undermine national health policies on tobacco.

Similar considerations apply to national criminal policies on the illicit tobacco trade. Total prohibition of tobacco, basically the criminalisation of tobacco, like the criminalisation of street market drugs, would turn smokers into criminals and consequently, encourage them to participate in the dark market. Subsequently, there would be no tax revenue for the state; worse quality products would further harm the health of users and underfunded law enforcement and eventual increase in crime levels would place huge burdens on society.

On the other hand, total decriminalization of tobacco, as well as waiving the excise tax on tobacco is also unthinkable; mainly due to health concerns, but also because of national fiscal needs.

As mentioned in this study, national criminal policy is always a result of an effort to combine a variety of factors in a comprehensive manner. National criminal policy on illicit tobacco trade is a good example of such a struggle. Given the results of the comparative study conducted in this volume, we must appreciate that the makers of 
the national criminal policy on illicit tobacco trade are between Scylla of health concerns and Charybdis of their own fiscal interests. There is no good solution, no one perfect criminal policy, or rather, there are no better criminal policies than states currently have. They are striving to find a delicate balance between health concerns and states' fiscal needs, considering requirements of the national legal systems and national criminal policies in general, as well as particular social and economic circumstances in the country, mainly related to pricing tobacco products, as well as in other countries. But there is no doubt that as long as there is no tobacco-free world, there is a need for a comprehensive and well-designed criminal policy on illicit tobacco trade.

Konrad Buczkowski Ph.D., is Assistant Professor at the Institute of Law Studies, Polish Academy of Sciences, Poland. His main research interest is criminology, however in addition he has a vast experience in the field of economic criminal law, especially: economic crime, insurance fraud, money laundering, white-collar crime and cybercrime. He is a member of the European Society of Criminology and the Member of the Board of the Polish Society of Criminology.

Celina Nowak Ph.D., is Associate Professor and Head of the Institute of Law Studies of the Polish Academy of Sciences. She holds a Ph.D. and habilitation in law, as well as a postgraduate diploma of Université de Paris I-Panthéon-Sorbonne in criminal law and criminal policy in Europe. Her research refers to criminal law, with focus on international, EU and comparative criminal law. In addition, she has extensive experience as an academic teacher at the Kozminski University and the Warsaw University. Prof. Nowak has taken part in a number of comparative law projects, in the national and EU context, either as a project leader, or as a national expert. She has authored 2 monographs, edited and co-edited 10 books. She has written more than three dozen articles and chapters in Polish, English and French, published in Poland and internationally.

Open Access This chapter is licensed under the terms of the Creative Commons Attribution 4.0 International License (http://creativecommons.org/licenses/by/4.0/), which permits use, sharing, adaptation, distribution and reproduction in any medium or format, as long as you give appropriate credit to the original author(s) and the source, provide a link to the Creative Commons licence and indicate if changes were made.

The images or other third party material in this chapter are included in the chapter's Creative Commons licence, unless indicated otherwise in a credit line to the material. If material is not included in the chapter's Creative Commons licence and your intended use is not permitted by statutory regulation or exceeds the permitted use, you will need to obtain permission directly from the copyright holder.

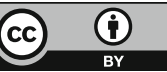

